\title{
Seasonal and Spatial Distribution of Caffeine, Atrazine, Atenolol and DEET in Surface and Drinking Waters from the Brazilian Federal District
}

\author{
Fernando F. Sodré, ${ }^{*, a}$ Joyce S. Santana, ${ }^{a}$ Thiago R. Sampaio ${ }^{a}$ and \\ Cristina C. S. Brandão ${ }^{b}$ \\ anstituto de Química, Universidade de Brasília, 70910-900 Brasília-DF, Brazil \\ ${ }^{b}$ Departamento de Engenharia Civil e Ambiental, Universidade de Brasília, \\ 70910-900 Brasília-DF, Brazil
}

\begin{abstract}
Selected emerging contaminants in water samples from the Brazilian capital were investigated by liquid chromatography-mass spectrometry after solid-phase extraction. In Paranoá Lake, an urban reservoir that will be used to produce drinking water, caffeine was the most abundant contaminant found (average of $53 \mathrm{ng} \mathrm{L}^{-1}$ ), followed by atenolol (34 $\left.\mathrm{ng} \mathrm{L}^{-1}\right), N, N$-diethyl-metatoluamide (DEET, $\left.12 \mathrm{ng} \mathrm{L}^{-1}\right)$ and atrazine $\left(3.8 \mathrm{ng} \mathrm{L}^{-1}\right)$. The role of wastewaters discharges could not be evidenced probably due to the water flow and circulation in the lake. However, higher concentrations were detected during the dry season suggesting the presence of point sources, except for atrazine. In source waters, concentrations were lower in comparison with Paranoá Lake waters. Environmental risk assessment shows the need for further surveys for atrazine. For drinking waters, only caffeine and atrazine were detected at average concentrations of 8.6 and $3.2 \mathrm{ng} \mathrm{L}^{-1}$, respectively. No risk for human health was observed.
\end{abstract}

Keywords: emerging contaminants, micropollutants, source waters, drinking waters, water reuse

\section{Introduction}

Emerging contaminants are commonly originated from direct wastewater disposal and hygiene/excretion mechanisms commonly practiced in large cities. ${ }^{1}$ Raw and treated wastewater reaches receiving waters leading to the occurrence of a wide variety of chemicals of recent interest, especially in Brazil, where this pollution mechanism is still an important issue when water quality is evaluated., ${ }^{2,3}$ A recent diagnosis on the sanitation scenario in Brazil revealed that $46.2 \%$ of sewage is collected and only a small fraction of this portion, i.e., $37.8 \%$ is actually treated. ${ }^{4}$ The region of the Brazilian Federal District (FD), however, is an exception since $93.7 \%$ of the population is served with domestic sewer systems and almost all collected sewage is treated. In addition, industrial activities are scarce in FD turning this region into a potential reference for comparisons with other Brazilian urban regions.

The capital of Brazil, Brasília, is a planned city founded in 1960 and is located in the heart of the FD. It was originally conceived to have 500,000 inhabitants, but the population growth was higher than expected and FD

*e-mail: ffsodre@unb.br reached its original population rate in only ten years. ${ }^{5}$ Today, FD has more than 3.0 million inhabitants, and faces a major water crisis, corroborated by its typical tropical savannah climate with several low flow water sources. To alleviate the low humidity effects on the region, Paranoá Lake $\left(37.5 \mathrm{~km}^{2}\right.$ and $\left.498 \times 10^{6} \mathrm{~m}^{3}\right)$ was also planned during the city's conception and today receives urban storm waters and effluents from two wastewater treatment plants (WWTP) in the southern and northern regions ${ }^{6,7}$ In addition, Paranoá Lake will be used in the coming years as a water source for the production of drinking water. Therefore, investigations on the presence of emerging contaminants can provide additional information considering the safe use of water.

The concentration of emerging contaminants in Paranoá Lake was previously reported by da Costa et al. ${ }^{8}$ The authors investigated the occurrence of caffeine, bezafibrate (pharmaceuticals), bisphenol A, diethyl phthalate and nonylphenol (industrial/domestic use) in five points along the lake and showed that the first substance was the most abundant chemical with concentrations ranging from 68 to $212 \mathrm{ng} \mathrm{L}^{-1}$. Also, higher levels were observed in the branches affected by discharges of the two WWTPs. Majewsky et al. ${ }^{9}$ investigated the presence of five emerging micropollutants in Paranoá Lake to support integrated 
water resource management projects. The polar chemicals iopromide, iohexol (X-ray contrast agents), carbamazepine (anti-epileptic drug), sucralose and acesulfame (artificial sweeteners), were assessed in 36 samples collected in six points of the lake, including the branches impacted by WWTPs discharges. Sucralose was the most abundant contaminant with median concentration around $142 \mathrm{ng} \mathrm{L}^{-1}$ followed by acesulfame (64 $\left.\mathrm{ng} \mathrm{L}^{-1}\right)$, iopromide $\left(27 \mathrm{ng} \mathrm{L}^{-1}\right)$, carbazazepine (14 $\left.\mathrm{ng} \mathrm{L}^{-1}\right)$ and iohexol $\left(10 \mathrm{ng} \mathrm{L}^{-1}\right)$.

Abbt-Braun et al..$^{10}$ carried out an extensive investigation in the Paranoá Lake through the determination of 42 micropollutants including pharmaceuticals, pesticides (30 samples), sweeteners and perfluorinated chemicals (12 samples). Concentrations of the most investigated substances decreased with the increasing distance from the WWTPs because of dilution and possible natural attenuation processes such as photolysis and degradation. The authors also show that all contaminants, except for caffeine and iopromide, did not exceeded $100 \mathrm{ng} \mathrm{L}^{-1}$ at the site of the future raw water extraction for drinking water production.

All reports involving the presence of emerging contaminants in FD waters were carried out at Paranoá Lake considering the historical importance of this body of water to the city as well as its future multiple use possibilities. However, seasonal variations on the concentration of such contaminants in the lake were never explored elsewhere, especially when it is assumed that concentrations of pharmaceuticals in Brazilian waters may vary significantly during dry and wet seasons. ${ }^{11,12}$ In addition, FD is in the Brazilian Central Plateau where the climate is characterized by two notably distinct seasons: a rainy season, from October to April, and a dry season, from May to September. Thus, this work aimed to investigate the seasonal variation of selected emerging contaminants in the Paranoá Lake branches affected by WWTP discharges as well as to assess the levels of such contaminants in water sources and drinking waters of the FD in order to establish a comparative scenario between the waters of FD and other Brazilian waters impacted by raw sewage discharges.

\section{Experimental}

\section{Chemicals}

Four microcontaminants were selected as they can be assigned to an anthropogenic origin and therefore can be used as indicator substances of our lifestyle, i.e., the pharmaceuticals caffeine and atenolol, the insect repellent $\operatorname{DEET}(N, N$-diethyl-meta-toluamide) and herbicide atrazine. All standards were obtained from Fluka Analytical (Milwaukee, USA), except for atenolol which was purchased from Sigma-Aldrich (St. Louis, USA). The chemical structures of the target chemicals are presented in Figure 1. Stock solutions (10 $\left.\mathrm{mg} \mathrm{L}^{-1}\right)$ were individually prepared in methanol. Standard mixtures were made using a 50:50 (v/v) solution of water:acetonitrile enriched with formic acid and ammonium formiate $(0.05 \%)$.
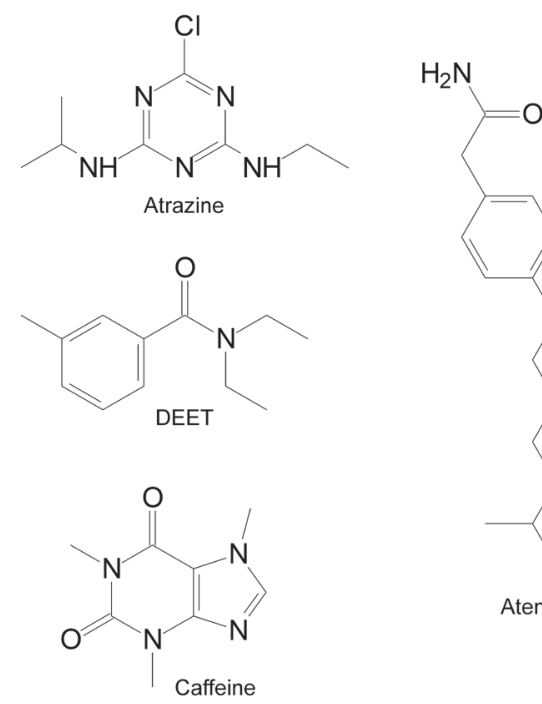

Figure 1. Chemical structures of the selected emerging contaminants investigated in this work.

Solvents were high purity, HPLC or pesticide grade. Methanol was purchased from Honeywell International (Muskegon, USA) and acetonitrile was obtained from Tedia (Fairfield, USA). LC-MS grade formic acid (98\%) was provided by Fluka Analytical (Milwaukee, USA) and ammonium formiate (98\%) by Riedel-de Häen (Seelze, Germany). Ultrapure water was produced by a Milli-Q Academic system (Millipore, Bedford, USA). Nitrogen for drying (98\% of purity) was supplied from White Martins (Rio de Janeiro, Brazil).

\section{Study area and sampling locations}

In the FD, raw sewage is treated in 16 WWTPs. At the north branch of the lake, named Bananal Branch, the North-Wing WWTP serves a population of 150,000 people from the cities of Brasília (north wing region), Lago Norte, Varjão and Estrutural. At the Riacho Fundo Branch, the South-Wing WWTP serves about 550,000 inhabitants from Brasília (south wing), Lago Sul, Guará, Núcleo Bandeirantes, Candagolândia, Águas Claras and Cruzeiro.

Figure 2 shows the location of the sampling points at Bananal (PL1 and PL2) and Riacho Fundo branches (PL3 and PL4), nearby the two WWTPs at Paranoá Lake. In this lake, water flows from west to east. In addition to the sampling points at Paranoá Lake two other aquatic systems 


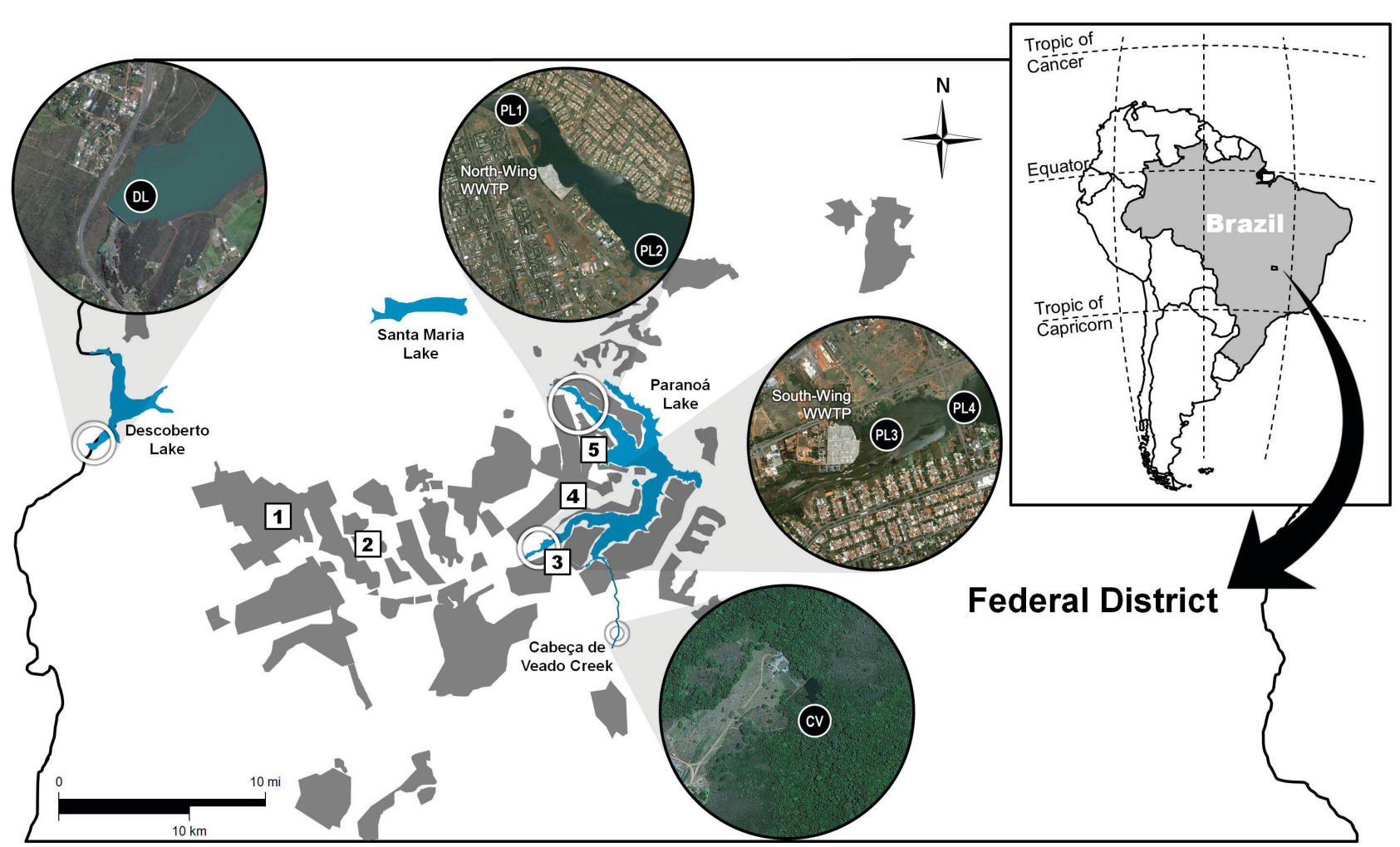

Figure 2. Map showing the Federal District in Brazil and the sampling points selected for surface and drinking water. DL: Descoberto Lake, PL: Paranoá Lake, CV: Cabeça-de-Veado Creek. Points numbered from 1 to 5 stands for drinking water (DW) sampling points.

were investigated in this work: Descoberto Lake (DL) and Cabeça-de-Veado Creek (CV). In the FD, drinking water is supplied from five production systems, namely Descoberto, Torto-Santa Maria, Sobradinho-Planaltina, Brazlândia and São Sebastião. Descoberto Lake $\left(4500 \mathrm{~L} \mathrm{~s}^{-1}\right)$ is the main source of the Descoberto production system, whereas Cabeça-de-Veado Creek $\left(90 \mathrm{~L} \mathrm{~s}^{-1}\right)$ is one of the sources of the Torto-Santa Maria production system. Five drinking water sampling points were also selected in this work. Sampling points DW1 and DW2, located in the cities of Ceilândia and Águas Claras, respectively, are representatives of the Descoberto production system. In the Lago Sul area, sampling point DW3 is mainly influenced by the water extracted from the Cabeça-de-Veado Creek (Torto-Santa Maria production system). The sampling point located in the south wing of Brasília (DW4) receives mixed waters from both Descoberto and Torto-Santa Maria systems, whereas sampling point DW5, in the north wing of Brasília, is connected to the Torto-Santa Maria production system.

\section{Sampling and sample preparation}

Sampling was carried out in September, covering the end of the dry season, and in April/May, comprising the end of the rainy season. During the dry winter, FD remains to 100-120 days without any rain events, placing it as one of the Brazilian regions that faces severe problems related to water scarcity. However, at the summer there are intense storm events as well as some intermittent floods. Under these unique conditions, a seasonal comparison can be performed. Source and lake water samples were collected in the surface using a pre-cleaned polypropylene plastic bailer and transferred into amber glass bottles (4 L) previously cleaned and rinsed with the sampled water on site. Drinking water samples were collected directly into amber glass bottles from taps connected to the local water supply system. In the laboratory, samples were passed through one or more $0.45 \mu \mathrm{m}$ pored-sized nitrocellulose membrane (Millipore) in order to obtain the operationallydefined dissolved sample.

Filtered samples were submitted to solid phase extraction (SPE), in triplicates, according to the method described by Machado et al. ${ }^{3}$ This method was developed by a collaborative initiative involving different Brazilian universities as part of the National Institute for Advanced Analytical Science and Technology (INCTAA). Briefly, samples (1 L) were passed through $500 \mathrm{mg}$ HLB Oasis cartridges (Waters, Milford, USA) fitted to a labmade extraction system ${ }^{13}$ coupled to a peristaltic pump (Minipuls Evolution, Gilson, Villiers le Bel, France). Conditioning was performed using $6 \mathrm{~mL}$ of methanol followed by $6 \mathrm{~mL}$ of 
reagent water. Samples were then passed through the solid phase at a flow rate of $10 \mathrm{~mL} \mathrm{~min}^{-1}$. After the extraction step, the solid phase was dried with $\mathrm{N}_{2}$ for $20 \mathrm{~min}$. Target compounds were recovered with two aliquots of $3 \mathrm{~mL}$ of methanol. The elution step was carried out in a 12-port Prep Sep vacuum manifold (Visiprep DL, Supelco, Bellefonte, USA) using pre-cleaned glass tubes. Solvents were carefully evaporated to dryness with a gentle flow of $\mathrm{N}_{2}$ and the target compounds were re-suspended to a final volume of $1.0 \mathrm{~mL}$ in a methanol solution.

\section{Determination by LC-MS/MS}

The analytical system consisted on a liquid chromatograph (Agilent 1200 Series, Santa Clara, USA) coupled to a mass spectrometer system (LC-MS/MS, AB Sciex 3200 triple quadrupole, Foster City, USA) with a turbo-ion electrospray ionization (ESI) module operating at $700{ }^{\circ} \mathrm{C}$ and $4000 \mathrm{~V}$, with nitrogen as curtain gas at 20 psi and as auxiliary nebulizing gas at 50 psi (GS1) and 40 psi (GS2). Details on the optimization of instrumental parameters are shown in Figures S1 to S6 in the Supplementary Information (SI) section. Separation was performed using a Hichrom RP 18-5 column $(4.0 \times 125 \mathrm{~mm}$, particle size of $5 \mu \mathrm{m}$, LiChrospher, Merck, Darmstadt, Germany) at $25{ }^{\circ} \mathrm{C}$. Different mobile phase additives, detailed in SI section, were tested in order to achieve good separation and high sensitivity. After optimization, an ammonium formiate/formic acid buffer solution, prepared in water:acetonitrile $(1: 1 \mathrm{v} / \mathrm{v})$ was used as mobile phase at a flow rate of $0.3 \mathrm{~mL} \mathrm{~min}^{-1}$ in the isocratic mode. The injection volume varied between 5.0 and $10.0 \mu \mathrm{L}$.

The triple quadrupole was operated in the multiple reaction monitoring (MRM) mode in order to identify and quantify the target analytes. All MRM parameters were obtained by successive injections in the chromatographicspectrometric system and are portrayed in Table 1 alongside other instrumental and method parameters. Additional analytical parameters are available in SI section.

\section{Risk assessment}

Environmental risk was assessed by calculating the risk quotient (RQ) based on the MEC/PNEC ratio, where MEC stands for the measured environmental concentrations obtained in the surface water samples and PNEC the predicted non-effect concentration. The RQ was calculated considering the most restrictive PNEC found in the literature for each investigated contaminant. Human health risks were evaluated by comparing the target chemicals concentrations in drinking water with a water quality criteria (WQC) calculated using the equation 1.

$\mathrm{WQC}=\frac{\mathrm{TDI} \times \mathrm{P} \times \mathrm{BW}}{\mathrm{C}}$

where TDI is the total daily intake, in $\mathrm{mg} \mathrm{kg}^{-1}, \mathrm{P}$ is the allocation factor considering the percentage of the contaminant ingested via water consumption, $\mathrm{BW}$ is the body weight and $\mathrm{C}$ is the daily water consumption. Default values for P (20\%), BW (60 kg) and C (2 L) were used considering water consumption for an adult according to the Guidelines for Drinking-Water Quality. ${ }^{14}$

\section{Results and Discussion}

Table 2 shows the concentration of the selected emerging contaminants in the samples. All analytes were quantified in the samples collected in Paranoá Lake, except

Table 1. LC-MS/MS and method parameters used during the analysis

\begin{tabular}{|c|c|c|c|c|c|c|c|c|c|}
\hline Analyte & $\mathrm{DP} / \mathrm{V}$ & $\begin{array}{c}\text { MRM transitions } \\
\qquad(\mathrm{m} / \mathrm{z})\end{array}$ & $\mathrm{CE} / \mathrm{V}$ & $\mathrm{EP} / \mathrm{V}$ & $\mathrm{CEP} / \mathrm{V}$ & $\mathrm{CXP} / \mathrm{V}$ & $t_{R} / \min$ & $\begin{array}{l}\mathrm{LOD} / \\
\left(\mathrm{ng} \mathrm{L}^{-1}\right)\end{array}$ & $\begin{array}{l}\mathrm{LOQ} / \\
\left(\mathrm{ng} \mathrm{L}^{-1}\right)\end{array}$ \\
\hline Atenolol & 46 & $\begin{array}{l}267.2 \rightarrow 190.0^{\mathrm{a}} \\
267.2 \rightarrow 145.0\end{array}$ & $\begin{array}{l}23 \\
35\end{array}$ & 3 & 16 & 4 & 1.9 & 0.71 & 2.09 \\
\hline Atrazine & 46 & $\begin{array}{l}216.2 \rightarrow 174.3^{a} \\
216.2 \rightarrow 104.1 \\
216.2 \rightarrow 132.1\end{array}$ & $\begin{array}{l}23 \\
37 \\
29\end{array}$ & 10 & 14 & 4 & 4.4 & 0.27 & 0.53 \\
\hline Caffeine & 51 & $\begin{array}{l}195.2 \rightarrow 138.3^{\mathrm{a}} \\
195.2 \rightarrow 110.2 \\
195.2 \rightarrow 123.2\end{array}$ & $\begin{array}{l}23 \\
31 \\
39\end{array}$ & 5 & 12 & 4 & 1.4 & 0.32 & 1.01 \\
\hline DEET & 41 & $\begin{array}{l}192.2 \rightarrow 119.2^{\mathrm{a}} \\
192.2 \rightarrow 65.2 \\
192.2 \rightarrow 91.20\end{array}$ & $\begin{array}{l}23 \\
59 \\
39\end{array}$ & 5 & 12 & 4 & 4.7 & 0.76 & 2.37 \\
\hline
\end{tabular}

Transitions used for quantification. MRM: multiple reaction monitoring; DP: declustering potential; CE: collision energy; EP: entrance potential; CEP: collision cell entrance potential; CXP: collision cell exit potential; $\mathrm{t}_{\mathrm{R}}$ : retention time; LOD: method limit of detection (signal-to-noise ratio of 3); LOQ: method limit of quantification (signal-to-noise ratio of 10 ); DEET: $N, N$-diethyl-meta-toluamide. 
Table 2. Concentrations of the selected emerging contaminants in surface and drinking water samples collected during the dry and rainy seasons

\begin{tabular}{|c|c|c|c|c|}
\hline Sampling point & Atenolol / $\left(\mathrm{ng} \mathrm{L}^{-1}\right)$ & Atrazine / $\left(\mathrm{ng} \mathrm{L}^{-1}\right)$ & Caffeine / $\left(\mathrm{ng} \mathrm{L}^{-1}\right)$ & DEET / $\left(\mathrm{ng} \mathrm{L}^{-1}\right)$ \\
\hline \multicolumn{5}{|c|}{ Dry season } \\
\hline PL1 & $39 \pm 2$ & $4.9 \pm 0.4$ & $85 \pm 4$ & $14 \pm 2$ \\
\hline PL2 & $30 \pm 3$ & $5.5 \pm 0.4$ & $68.7 \pm 0.4$ & $16.3 \pm 0.3$ \\
\hline PL3 & $70 \pm 6$ & $<\mathrm{LOQ}$ & $228 \pm 18$ & $26 \pm 5$ \\
\hline PL4 & $90 \pm 19$ & $1.2 \pm 0.9$ & $142 \pm 19$ & $19 \pm 5$ \\
\hline DL & ND & $<\mathrm{LOQ}$ & $10 \pm 1$ & $2.6 \pm 0.9$ \\
\hline $\mathrm{CV}$ & ND & ND & $2 \pm 1$ & $2.38 \pm 0.04$ \\
\hline DW1 & ND & $2.2 \pm 0.5$ & $16 \pm 10$ & ND \\
\hline DW2 & ND & $2 \pm 1$ & $13 \pm 5$ & ND \\
\hline DW3 & ND & $<\mathrm{LOQ}$ & $4.0 \pm 0.9$ & ND \\
\hline DW4 & ND & $<\mathrm{LOQ}$ & $2 \pm 2$ & ND \\
\hline DW5 & ND & $2 \pm 2$ & $<\mathrm{LOQ}$ & ND \\
\hline \multicolumn{5}{|c|}{ Rainy season } \\
\hline PL1 & $12.1 \pm 0.5$ & $2.9 \pm 0.3$ & $22.6 \pm 0.6$ & $3.8 \pm 0.3$ \\
\hline PL2 & $4.7 \pm 0.5$ & $4 \pm 1$ & $20.1 \pm 0.9$ & $4 \pm 2$ \\
\hline PL3 & $19 \pm 2$ & $3.6 \pm 0.6$ & $29 \pm 3$ & $17.4 \pm 0.5$ \\
\hline PL4 & $13 \pm 2$ & $5.2 \pm 0.9$ & $13 \pm 2$ & $10.0 \pm 0.8$ \\
\hline DL & ND & $3.7 \pm 0.6$ & $9 \pm 1$ & ND \\
\hline $\mathrm{CV}$ & ND & ND & $3.2 \pm 0.6$ & ND \\
\hline DW1 & ND & $3 \pm 1$ & $14 \pm 2$ & ND \\
\hline DW2 & ND & $3.3 \pm 0.8$ & $12.3 \pm 0.7$ & ND \\
\hline DW3 & ND & $<\mathrm{LOQ}$ & $3.6 \pm 0.9$ & ND \\
\hline DW4 & ND & $<\mathrm{LOQ}$ & $4 \pm 1$ & ND \\
\hline DW5 & ND & $<$ LOQ & $13 \pm 1$ & ND \\
\hline
\end{tabular}

DEET: N,N-diethyl-meta-toluamide; PL: Paranoá Lake; DL: Descoberto Lake; CV: Cabeça-de-Veado Creek; DW: drinking water; ND: not detected; LOQ: limit of quantification.

for atrazine during the dry season at PL3. Results show a frequency of detection of $100 \%$ for all the analytes in the samples from Paranoá Lake. In the source waters, caffeine was detected in all samples followed by DEET, detected in $75 \%$. In these waters, atenolol was not detected, and atrazine was detected once at a concentration below limit of quantification (LOQ). In drinking waters, only caffeine and atrazine were detected.

Caffeine was the most abundant contaminant in the surface waters with concentrations ranging from $2 \pm 1$ to $228 \pm 18 \mathrm{ng} \mathrm{L}^{-1}$. Many studies show that the presence of caffeine in surface waters can be used do indicate the degree of human activities, ${ }^{15}$ especially those associated with wastewater inputs. ${ }^{16-18}$ In Brazil, caffeine was also investigated in previous works as a marker for sewageimpacted aquatic systems. ${ }^{2,19,20}$

Atenolol was the second most abundant contaminant with levels varying from $4.7 \pm 0.5$ to $90 \pm 19 \mathrm{ng} \mathrm{L}^{-1}$. It is a beta-blocker drug type widely used to control cardiovascular diseases and hypertension. Renal excretion of atenolol ranges from 40 to $50 \%$ of total consumed drug and the excretion in feces represents $50 \%$.

In the surface waters, DEET presented concentrations between $2.38 \pm 0.04$ and $26 \pm 5 \mathrm{ng} \mathrm{L}^{-1}$ evidencing its frequent use as an insect repellent by the FD population. When used as personal care product, a percentage up to $20 \%$ can be absorbed through the skin and thereafter metabolized and excreted. ${ }^{21}$ Thus, the most important pathway for DEET into aquatic environments is wastewater inputs after washing off and excretion performed by humans. ${ }^{22}$

Finally, atrazine was found at the lowest concentrations in surface waters, between $1.2 \pm 0.9$ to $5.5 \pm 0.4 \mathrm{ng} \mathrm{L}^{-1}$. Atrazine is an herbicide from the group of triazines, widely used in crops of sugarcane and corn. It is one of the most used pesticides in Brazil, being on the top of the commercialized active ingredients ranking of 2009-2012. ${ }^{23}$ However, activities in the FD are mostly domestic and commercial, while industrial and crop areas are relatively 
scarce. On the other hand, the studied region presents wide areas with green vegetation which implies in possible uses of agrochemicals for pest control in gardens, buildings facades and yards. Thus, the relatively low concentration of this herbicide may be associated with its minor use in urban environments compared to rural areas.

\section{Emerging contaminants in the Paranoá Lake}

Figure 3 shows the concentration of the four investigated contaminants in the Paranoá Lake in samples collected during dry and rainy seasons. At the Bananal Branch, sampling points PL1 and PL2 were located upstream and downstream of the North-Wing WWTP, respectively, whereas at Riacho Fundo Branch, both sampling points (PL3 and PL 4) were located downstream of the South-Wing WWTP due to logistics difficulties in accessing the upstream portion of the Branch.

For caffeine, atenolol and DEET, concentrations in the Riacho Fundo Branch were higher in comparison with the Bananal Branch in both investigated seasons. Similar results were observed by da Costa et al. ${ }^{8}$ investigating the levels of caffeine, bezafibrate and bisphenol A in samples from the same lake collected in a depth of $10 \mathrm{~m}$. However, higher concentrations were reported by the authors at the Bananal Branch at a depth of $1 \mathrm{~m}$. This behavior shows that water mixture in lakes has an important impact on contaminant transport. For diethyl phthalate, all results from da Costa et al. ${ }^{8}$ showed higher levels at the Bananal Branch while nonylphenol was more abundant at the Riacho Fundo Branch. Our results show that in this portion of the lake, caffeine concentration was higher in the sampling point immediately after the WWTP (PL3) and diminished at the subsequent sampling point (PL4) indicating a possible dilution and/or degradation. Lorz et al. ${ }^{7}$ showed that the concentration of organic micropollutants in Paranoá Lake decreases significantly as the distance to WWTPs becomes higher, probably due to the fast and efficient degradation processes triggered by high water temperatures and permanent UV irradiation. However, their conclusions were based on data collected from sampling points situated in different locations of the lake, i.e., one in each of the four branches and another nearby the dam at the eastside portion of the lake.

In the present work, the same behavior observed for caffeine could be noticed for atenolol and DEET at the rainy season, since at the dry season concentrations were slightly, but not significantly, higher at PL4. At this region, Paranoá Lake receives effluents from the South-Wing WWTP as well as from combined and sanitary sewers. ${ }^{24}$ Also, due to the proximity of the sampling points, a complete mixture of the lake water could not be achieved after the effluent discharge due to aspects such as water stratification, flow differences alongside the branch and winds. At the Bananal Branch, similar concentrations were noticed for the samples collected in both upstream and downstream sites
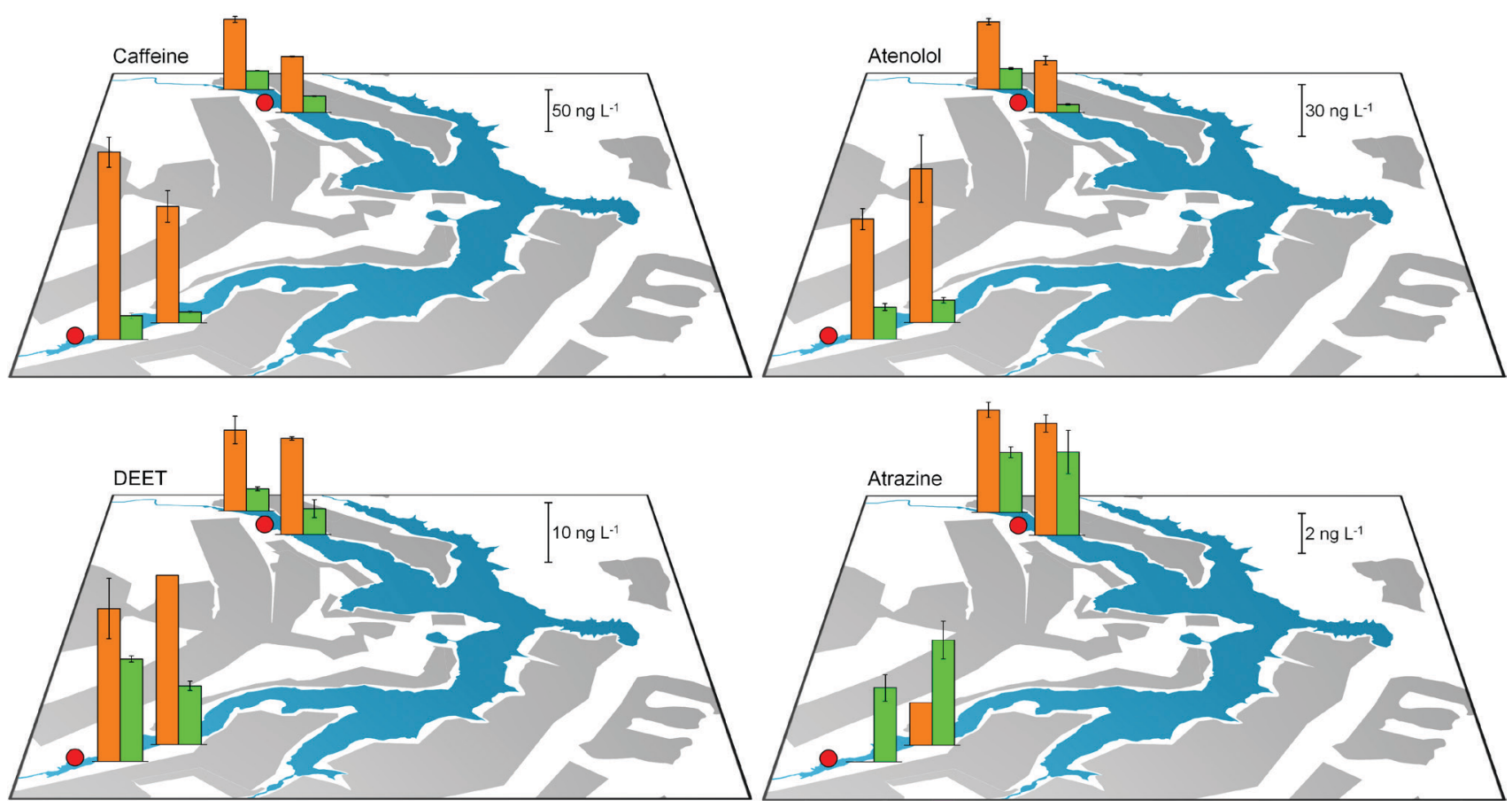

Figure 3. Concentration of the selected emerging contaminants in the Paranoá Lake during the dry season (orange bars) and the rainy season (green bars). Red circles indicate the position of the WWTPs. 
of the WWTP, making difficult to stablish a relationship between lake water contamination and discharges from the North-Wing WWTP.

Previous works have reported higher concentrations in sampling points located upstream of WWTPs in comparison with downstream sites. Mavura and Wangila ${ }^{25}$ investigated the pollution of Lake Nakuru (Kenya) by heavy metals and pesticide residues and observed that some contaminants presented slightly higher concentrations upstream of a WWTP, probably due to point sources discharges followed by dilution. Similar conclusion were made by Chiffre et al..$^{26}$ studying the occurrence of pharmaceuticals in the Doubs and Loue rivers, in France. Among the 31 chemicals investigated, oxazepam, carbamazepine, atenolol, trimethoprim and estrone were detected at higher concentrations upstream of a WWTP in the Doubs River, whereas in the Loue River, the same pattern was depicted for paracetamol and progesterone. Authors suggested that the occurrence of pharmaceuticals in upstream sites could be a consequence of buildings not connected to the sewage network and/or by sewage overflow.

The influence of both point and diffuse sources, was suggested by Wilkinson et al. ${ }^{27}$ to explain higher levels of benzoylecgonine (the major cocaine metabolite) and HAP (a transformation product of bisphenol A) in sites upstream of a WWTP in the Hogsmill River, in England. Kolpin et al. ${ }^{28}$ observed no significant differences in the levels of emerging contaminants determined in samples collected in sites located upstream and downstream of urban areas as a result of the water flow conditions, where the dilutional effect increases at progressively higher streamflows.

Numerous reports in the literature suggested that higher contaminant concentrations in upstream sites may be a consequence of sewage-derived sources and diffuse sources such as surface runoff. Thus, in order to corroborate to these hypothesis, one can consider the need to investigate the water quality of the tributaries of Paranoá Lake. Riacho Fundo is the most urban influenced tributary. ${ }^{29}$ Abbt-Braun et al. ${ }^{10}$ report that Riacho Fundo catchment has more than $50 \%$ of urban area, while $75 \%$ of the Bananal catchment belongs to natural and agricultural sites. Therefore, the influence of the Riacho Fundo stream to the contamination of Paranoá Lake, even upstream from the WWTP, is coherent, but the same conclusion cannot be made to the Bananal Branch.

The Bananal stream flows into the Paranoá Lake passing through a more preserved region including the area of the National Park of Brasília. Although effluents generated in the park may be discharged into the Bananal stream, this hypothesis may not be sufficient to explain the behavior observed for the selected emerging contaminants in the
Bananal Branch of the lake. Another hypothesis is related to the lake water circulation. Higher levels upstream of the WWTP may be a consequence of wind cells formed in the lake, which can change water circulation. Our samples were collected in the surface layer of the lake where water direction may change by the transfer of momentum from winds. The variation on the water flow direction in the surface layer can also be a consequence of the lake surroundings as pointed out by Podsetchine and Schernewski, ${ }^{30}$ which evidenced that flow field can change according to spatial variation of wind speed due to sheltering effects of hills and vegetation. Finally, it is important to mention that the water flow of the tributaries is very low, making possible an upstream dispersion of the plume discharged by the WWTPs. This behavior is commonly observed in routine analysis performed in the same area by the Environmental Sanitation Company of the Federal District ${ }^{31}$ and may explain the dispersion observed for the emerging contaminants in this work.

Our results for Paranoá Lake were inconclusive to trace a direct influence of both WWTP in the concentrations of the selected emerging contaminants, as previously observed elsewhere. ${ }^{7-10}$ However, our data support that WWTP may be an important source of emerging contaminants if diffuse inputs and water circulation are considered. The latter aspect was also investigated by Goldscheider et al. ${ }^{32}$ in Geneva Lake (Switzerland) where contaminant transport does not occur by homogeneous mixing processes, but in the form of plumes with sharp boundaries, being not possible to draw an iso-concentration line between the measured concentrations. Finally, it is important to point out that the previous works carried out in Paranoá Lake based their conclusions using only one sampling point in each one of the lake branches, which facilitated their observations on the influence of WWTP. In our work, on the contrary, two sampling points were selected in both Bananal and Riacho Fundo branches, thus bringing new information about the spatial variability of the contaminants. Our results also show the need for more detailed studies in the lake in order to verify the influence of wind and water circulation on the dispersion of micropollutants.

In Figure 3, it is possible to observe that concentrations for all contaminants were significantly lower during the rainy season, except for atrazine. During this period, the occurrence of rainfall events contributes to the dilution of contaminants in the samples. Similarly, at the dry season, analytes may present higher concentrations due to the decrease of water flow. ${ }^{28}$ Obviously, this hypothesis takes into account a constant contribution of the contaminants from the WWTP, which cannot always be easy to investigate due to the variability of discrete and diffuse sources of 
pollution. Similar results were observed by Locatelli et al. ${ }^{11}$ investigating the concentration of antibiotics in different points of the Atibaia River Basin, in Brazil. Authors show an increase in the frequency of detection from 55 to $88 \%$ during the dry season as well as higher concentration of antibiotics during this period. Concentrations in the Salto Grande Lake, at the Atibaia River mouth, were also significantly higher during the dry season for five of the six antibiotics detected. At the Atibaia River, Montagner and Jardim $^{12}$ also observed higher concentrations of caffeine, acetaminophen, acetylsalicylic acid, 17b-estradiol and bisphenol A during the dry season. Results collected in the Paranoá Lake by Abbt-Braun et al. ${ }^{10}$ however, showed that caffeine levels do not followed any clear seasonal or spatial tendency probably as a consequence of diffuse discharges into tributaries and misconnections to rainwater drains.

In this work, higher concentrations during the rainy season was observed only for atrazine in both sampling points located in the Riacho Fundo Branch. Because herbicides are widely used in urban areas for weed control or biocidal applications, they may enter in wastewaters ${ }^{33}$ or be carried out through surface runoff. ${ }^{34}$ Its presence in the Riacho Fundo Branch may be a consequence of agricultural loads and/or improper handling followed by diffuse surface runoff. Considering the widespread use of atrazine in Brazil, this herbicide can be eventually used in the vast number of small parks and lawns across the FD despite of the small-scale agricultural areas. Abbt-Braun et al. ${ }^{10}$ also investigated herbicides variability in Paranoá Lake and showed that the discharge of Riacho Fundo stream could be an important source for diuron, an herbicide characterized by a mixed use of urban and agricultural catchments. Authors also concluded that herbicides detected in Paranoá Lake, as well as their metabolites, seem to follow a seasonal trend with higher frequencies of detection at the end of the rainy season. At the Bananal Branch, it is believed that atrazine loads may be influenced by both point and diffuse sources. Wittmer et al. ${ }^{35}$ shows that the presence of agricultural loads in urban WWTPs may be a consequence of single disposal activities, since atrazine was also found in WWTP samples. Benotti et al..$^{36}$ detected atrazine in waters far from agricultural activities where wastewater was the only known source of contamination.

\section{Emerging contaminants in source and drinking waters}

All emerging contaminants were detected at least once in the source waters, except for atenolol. Descoberto Lake is located in a relatively preserved region, near to an Environmental Protection Area, i.e., a protected area where natural resources are subject to conservation or sustainable uses and human occupation is monitored and more controlled. However, caffeine levels were significantly higher in Descoberto Lake $(9 \pm 1$ and $10 \pm 1 \mathrm{ng} \mathrm{L}^{-1}$ ) in comparison with Cabeça-de-Veado Creek ( $2 \pm 1$ and $3.2 \pm 0.6 \mathrm{ng} \mathrm{L}^{-1}$ ). In both water sources, caffeine levels were less influenced by seasonality in comparison with the behavior observed for the Paranoá Lake. Also, concentrations were similar in comparison with previous studies carried out in the same lake, ${ }^{37}$ but lower than other reports in the literature.

Wang et al..$^{38}$ investigated 31 source waters across the state of Missouri, in the United States, and found median caffeine concentrations of $70.3 \mathrm{ng} \mathrm{L}^{-1}$ for rivers, $26.2 \mathrm{ng} \mathrm{L}^{-1}$ for lakes and reservoirs and $6.7 \mathrm{ng} \mathrm{L}^{-1}$ for wells. Also in the United States, Focazio et al..$^{39}$ reported concentrations up to $270 \mathrm{ng} \mathrm{L}^{-1}$ in drinking water sources across the country. Caffeine levels were also investigated in different source waters from Lisbon, Portugal, by de Jesus Gaffney et al. ${ }^{40}$ The authors observed concentrations ranging from 30 to $46 \mathrm{ng} \mathrm{L}^{-1}$ in the rivers Tagus and Zêzere with highest levels credited to the discharge of WWTP effluents. In the region of Calgari, Canada, Chen et al. ${ }^{41}$ reported caffeine concentrations varying from 43 to $160 \mathrm{ng} \mathrm{L}^{-1}$ in the Bow River. Since sampling point was located upstream of the local WWTP, authors suggested that caffeine, as well as other pharmaceutically active compounds, entered the river through alternative pathways, such as improper discharges and/or private septic systems. In Brazil, Linden et al..$^{42}$ investigated the spatial distribution of caffeine in source waters of the Sinos River, in the Rio Grande do Sul State, at the southern part of the country. Results varied significantly, between 150 and $16720 \mathrm{ng} \mathrm{L}^{-1}$, reflecting the poor sanitation conditions of the area where high proportions of raw sewage are discharged into the waters. A concentration as high as the latter was found by Machado et al. ${ }^{3}$ investigating source waters from three Brazilian capitals. At the Billings Reservoir, one of the source waters from the city of São Paulo, caffeine was detected at a concentration of $18828 \mathrm{ng} \mathrm{L}^{-1}$, whereas in other production systems concentration ranged from 40 to $255 \mathrm{ng} \mathrm{L}^{-1}$. The authors also investigated source waters from the cities of Porto Alegre and Belo Horizonte. In the former capital, levels in Guaíba Lake ranged from 1733 to $2572 \mathrm{ng} \mathrm{L}^{-1}$, whereas concentrations of 262 and $1086 \mathrm{ng} \mathrm{L}^{-1}$ were found in the Vargem-das-Flores Reservoir and Rio-dasVelhas River, respectively, both source waters from the city of Belo Horizonte.

Atrazine was found only once during the rainy season at the Descoberto Lake, in a concentration of $3.7 \pm 0.6 \mathrm{ng} \mathrm{L}^{-1}$, being probably influenced by diffuse sources from adjacent green areas. Abbt-Braun and $\mathrm{Worch}^{37}$ found a similar concentration $\left(2 \mathrm{ng} \mathrm{L}^{-1}\right)$ at this lake during the rainy season 
indicating that pollution processes may be stable over the years. Atrazine concentrations in Descoberto Lake were also lower in comparison with other Brazilian source waters. The work of Machado et al..$^{3}$ showed an average concentration of $15 \mathrm{ng} \mathrm{L}^{-1}$ in the source waters from the city of São Paulo and $19 \mathrm{ng} \mathrm{L}^{-1}$ in the Vargem-das-Flores Reservoir at the city of Belo Horizonte. An atrazine concentration of $3 \mathrm{ng} \mathrm{L}^{-1}$, thus similar to our result, was found by the authors in the Guaíba Lake, in Porto Alegre. Villanueva et al ${ }^{43}$ reported average concentrations up to $94 \mathrm{ng} \mathrm{L}^{-1}$ in raw waters from 112 water distribution units of the district of Finistère, in France. Concentrations varying from 5 to $20 \mathrm{ng} \mathrm{L}^{-1}$ were determined in the Llobregat River, in Spain, by RodriguezMozaz et al. ${ }^{44}$ However, in one sample, the authors found atrazine at $463 \mathrm{ng} \mathrm{L}^{-1}$. Padhye et al. ${ }^{45}$ detected atrazine in all samples from a major drinking water supplier in the southeast United States at concentrations varying between 3.4 and $75 \mathrm{ng} \mathrm{L}^{-1}$ during a year-long study.

DEET was detected in both source waters, but only during the dry season indicating a contribution of anthropic inputs. Concentrations in Descoberto Lake and Cabeça-de-Veado Creek were $2.6 \pm 0.9$ and $2.38 \pm 0.04 \mathrm{ng} \mathrm{L}^{-1}$, respectively, being significantly lower than those detected in Paranoá Lake. Qiao et al. ${ }^{46}$ observed that maximum concentrations of caffeine and DEET did not exceed $2 \mathrm{ng} \mathrm{L}^{-1}$ in source waters from the Dongjiang River in China. Sun et al. ${ }^{47}$ found DEET in all source water samples collected in major watersheds of China, at concentrations between 0.8 and $10.2 \mathrm{ng} \mathrm{L}^{-1}$, probably as a result of the DEET resistance to natural degradation process. Padhye et al. ${ }^{45}$ also detected DEET in all source water samples from a major U.S. drinking water system, but at a higher median concentration (122 $\left.\mathrm{ng} \mathrm{L}^{-1}\right)$ in comparison with the work carried out in China. Benotti et al. ${ }^{36}$ reported a frequency of detection of $31 \%$ and a median DEET concentration of $85 \mathrm{ng} \mathrm{L}^{-1}$ in samples from 19 U.S. drinking water production systems. An average concentration of $120 \mathrm{ng} \mathrm{L}^{-1}$ was observed by Stackelberg et al..$^{48}$ in a highly urbanized drainage basin in United States.

In the present work caffeine and atrazine were detected in all drinking water samples. However, only half on the samples presented quantifiable concentrations for the latter, while for caffeine a frequency of quantification of $90 \%$ was noticed. Snyder ${ }^{49}$ shows that atrazine and caffeine are poorly removed during chlorine oxidation, commonly used in water treatment plants in Brazil. Although DEET is also poorly removed, ${ }^{49}$ this contaminant could not be detected in the drinking water samples from the FD. Atenolol was not detected in both source and drinking water samples.

There was no evidence of seasonal influence on the levels of caffeine and atrazine in the drinking water samples, agreeing with the data collected for the source waters. Atrazine concentrations varied between $2 \pm 1$ and $3.3 \pm 0.8 \mathrm{ng} \mathrm{L}^{-1}$, being detected in all samples from the Descoberto production system (DW1 and DW2). Again, these concentrations are lower than other data available elsewhere. In a previous work carried out in Brazil, atrazine concentrations varied between 2.0 and $24 \mathrm{ng} \mathrm{L}^{-1}$ in drinking water samples from 16 capitals. ${ }^{3}$ Benotti et al..$^{36}$ observed median concentrations of atrazine around $50 \mathrm{ng} \mathrm{L}^{-1}$ in finished and distribution drinking water as well as a frequency of detection of approximately $80 \%$. Authors also reported a discrepant concentration of $930 \mathrm{ng} \mathrm{L}^{-1} .36$ Median atrazine and caffeine concentrations up to 14.8 and $11.6 \mathrm{ng} \mathrm{L}^{-1}$, respectively, were observed by Padhye et al. ${ }^{45}$ investigating finished and drinking water from a major urban region of United States.

In the present work, caffeine levels ranged from $2 \pm 2$ to $16 \pm 10 \mathrm{ng} \mathrm{L}^{-1}$ indicating a significant spatial distribution of this contaminant in the FD as well as a high variability between replicates obtained in the sampling points. Higher levels were found in sampling points connected to the Descoberto production system, except for DW5 during the rainy season. The presence of caffeine in Brazilian drinking water, previously reported by Machado et al., ${ }^{3}$ varied from levels as low as those observed in this study to concentrations above $2000 \mathrm{ng} \mathrm{L}^{-1}$.

\section{Risk assessment to the environment and human health}

Risk quotients for aquatic life protection $\left(\mathrm{RQ}_{\mathrm{AL}}\right)$, expressed as ratios between MEC and PNEC, are portrayed in Figure 4. PNEC for atenolol (77700 $\mathrm{ng} \mathrm{L}^{-1}$ ) was estimated by Jones et al. ${ }^{50}$ using the software ECOSAR (Ecological Structure Activity Relationships) from the U.S. Environmental Protection Agency. For atrazine, a PNEC of $21 \mathrm{ng} \mathrm{L}^{-1}$ was derived by Girling et al. ${ }^{51}$ from acute toxicity data using the unicellular algae Scenedesmus subspicatus and an assessment factor of 1000 according to the guidelines from the European Commission. PNEC for DEET and caffeine (5200 $\left.\mathrm{ng} \mathrm{L}^{-1}\right)$ were based on no-observed effect concentration (NOEC) data for aquatic organisms using an assessment factor of 100. ${ }^{52,53}$ Figure 4 also shows risks quotients for human health $\left(\mathrm{RQ}_{\mathrm{Hн}}\right)$ calculated by the ratio between caffeine and atrazine levels in drinking water and their respective WQC. For atrazine, WQC corresponded to the maximum permissible level preconized by the Brazilian drinkingwater standards,${ }^{54}$ while for caffeine WQC was calculated according to equation 1 using a TDI of $0.003 \mathrm{mg} \mathrm{kg}^{-1}$ according to the lowest no-observed adverse effect level (NOAEL) compiled by Meltzer et al. ${ }^{55}$ 
In the present work, RQ analysis was based on the classification proposed by Komori et al. ${ }^{52}$ where values lower than 0.1 were considered acceptable, whereas ratios between 0.1 and 1 were classified as "needs further survey". Ratio quotients greater than or equal to 1 are those which "require detailed evaluation". In Figure 4, it is possible to observe that all results were considered acceptable except for most of the data compiled for atrazine in the surface water samples. In this case, $88 \%$ of the results are in the gray region of the graph indicating the need for further surveys.

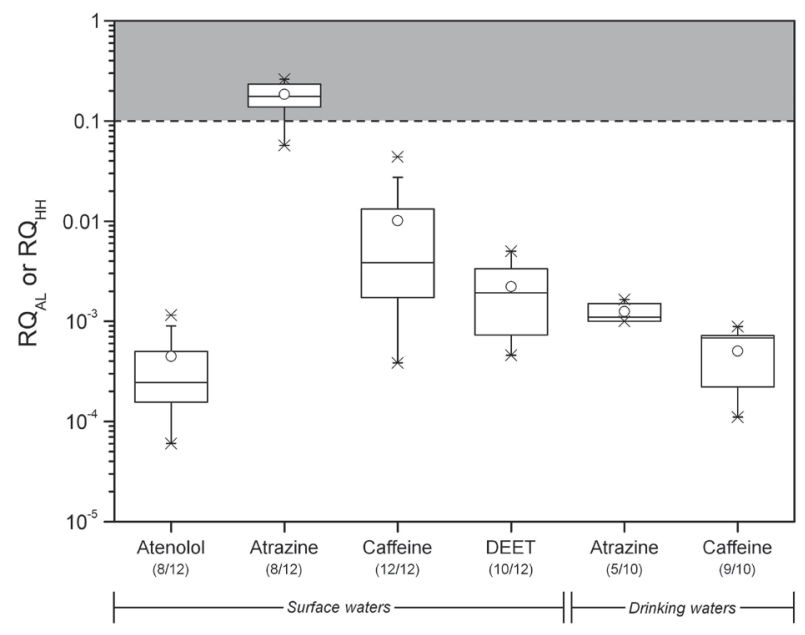

Figure 4. Box-plot distribution of risk quotients calculated for environmental $\left(\mathrm{RQ}_{\mathrm{AL}}\right)$ and human health $\left(\mathrm{RQ}_{\mathrm{HH}}\right)$ in surface and drinking water samples. The relationship between the number of positive results (> LOQ) and the number of samples evaluated is shown in parenthesis.

Although the RQ values for caffeine in the surface water samples were considered acceptable, its concentrations in the Paranoá Lake were relatively high, especially during the dry season. It is believed that similar levels may indicate the presence of other emerging contaminants, even though they have not been included in this work. Montagner et al. ${ }^{56}$ investigated the use of caffeine as a potential marker for estrogenic activity in Brazilian surface waters. Their results show that $67 \%$ of the samples with caffeine concentrations up to $100 \mathrm{ng} \mathrm{L}^{-1}$ presented estrogenic activity, probably as a result of other emerging contaminants with the potential to act as endocrine disrupting chemicals. Also, for caffeine concentrations between 100 and $1000 \mathrm{ng} \mathrm{L}^{-1}$, the percentage of samples with estrogenic activity increases to $92 \%$.

\section{Conclusions}

Caffeine, atrazine, atenolol and DEET were frequently detected in surface water samples from the Paranoá Lake in the Brazilian Federal District. Significantly higher concentrations were observed during the dry season for all emerging contaminants except for atrazine in the Riacho Fundo Brach indicating a diffuse origin for this herbicide. Our data were inconclusive to trace a direct influence of both WWTP in the water contamination. The expected influence of WWTPs on Paranoá Lake contamination was thus discussed considering evidences collected elsewhere as well as water circulation characteristics of the lake. Source water samples were also investigated revealing the presence of all contaminants except for atenolol. In these waters, concentration was usually lower when compared with other reports found in the literature. No evidence of seasonality was observed in source water samples, except for DEET. Environmental risk assessment, based on MEC/PNEC ratios, shows the need for further surveys for atrazine. For drinking water, only caffeine and atrazine were detected, but poses no risks to human health. Finally, it is important to mention that Paranoá Lake will be used in the near future as a source water for the production of drinking water, making our results important to subsidize further investigations in order to guarantee an adequate condition to protect both aquatic life and human health.

\section{Supplementary Information}

Supplementary information concerning method development and validation is available free of charge at http://jbcs.sbq.org.br as PDF file.

\section{Acknowledgments}

The authors are grateful to National Institute for Advanced Analytical Science and Technology (INCTAA), National Council for Scientific and Technological Development (CNPq Project 480410-2012-7) and Federal District Research Foundation (FAPDF 0193.000.714/2016) for funding. J. S. Santana and T. R. Sampaio also acknowledge Coordination for the Improvement of Higher Education Personnel (CAPES) for the fellowship.

\section{References}

1. Petrie, B.; Barden, R.; Kasprzyk-Hordern, B.; Water Res. 2014, $72,3$.

2. Sodré, F. F.; Locatelli, M. A. F.; Jardim, W. F.; Water, Air, Soil Pollut. 2010, 206, 57.

3. Machado, K. C.; Grassi, M. T.; Vidal, C.; Pescara, I. C.; Jardim, W. F.; Fernandes, A. N.; Sodré, F. F.; Almeida, F. V.; Santana, J. S.; Canela, M. C.; Nunes, C. R. O.; Bichinho, K. M.; Severo, F. J. R.; Sci. Total Environ. 2016, 572, 138.

4. http://www.snis.gov.br/diagnostico-agua-e-esgotos, accessed in June 2017. 
5. Ferrante, J. E. T.; Rancan, L.; Netto, P. B. In Olhares sobre o Lago Paranoá; Fonseca, F., ed.; Secretaria do Meio Ambiente e Recursos Hídricos: Brasília, Brazil, 2001, p. 45.

6. Mesquita, G. M.; de Souza, M. A. P.; Castro, M. N.; de Oliveira, A. P.; RENEFARA 2014, 5, 123.

7. Lorz, C.; Abbt-Braun, G.; Bakker, F.; Borges, P.; Börnick, H.; Fortes, L.; Frimmel, F. H.; Gaffron, A.; Hebben, N.; Höfer, R.; Makeschin, F.; Neder, K.; Roig, L. H.; Steiniger, B.; Strauch, M.; Walde, D.; Weiß, H.; Worch, E.; Wummel, J.; Environ. Earth Sci. 2012, 65, 1575.

8. da Costa, N. Y.; Boaventura, G. R.; Mulholland, D. S.; Araújo, D. F.; Moreira, R. C. A.; Faial, K. C. F.; Bomfim, E. O.; Environ. Earth Sci. 2016, 75, 854.

9. Majewsky, M.; Cavalcanti, C. B. G.; Cavalcanti, C. P.; Horn, H.; Frimmel, F. H.; Abbt-Braun, G.; Environ. Earth Sci. 2014, 72,4891 .

10. Abbt-Braun, G.; Börnick, H.; Brandão, C. C. S.; Cavalcanti, C. B. G.; Cavalcanti, C. P.; Frimmel, F. H.; Majewsky, M.; Steiniger, B.; Tröster, M.; Worch, E. In Integrated Water Resource Management in Brazil; Lorz, C.; Makeschin, F.; Weiss, H., eds.; IWA Publishing: London, England, 2014, p. 152.

11. Locatelli, M. A. F.; Sodré, F. F.; Jardim, W. F.; Arch. Environ. Contam. Toxicol. 2011, 60, 385.

12. Montagner, C. C.; Jardim, W. F.; J. Braz. Chem. Soc. 2011, 22, 1452.

13. Sodré, F. F.; Locatelli, M. A. F.; Jardim, W. F.; Quim. Nova 2010, 33, 216.

14. World Health Organization (WHO); Guidelines for DrinkingWater Quality, $4^{\text {th }}$ ed.; WHO Press: Geneva, Switzerland, 2011, p. 564.

15. Siegener, R.; Chen, R. F. In Analysis of Environmental Endocrine Disruptors; Keith, L. H.; Jones-Lepp, T. L.; Needham, L. L., eds.; American Chemical Society: Washington, USA, 1999, p. 125.

16. Young, T. A.; Heidler, J.; Matos-Pérez, C. R.; Sapkota, A.; Toler, T.; Gibson, K. E.; Schwab, K. J.; Halden, R. U.; Environ. Sci. Technol. 2008, 42, 3335.

17. Vystavna, Y.; le Coustumer, P.; Huneau, F.; Environ. Monit. Assess. 2013, 185, 3581.

18. Paíga, P.; Delerue-Matos, C.; Mar. Pollut. Bull. 2017, 120, 355.

19. Gonçalves, E. S.; Rodrigues, S. V.; da Silva-Filho, E. V.; Rev. Ambient. Agua 2017, 12, 192.

20. Ferreira, A. P.; de Lourdes, C.; da Cunha, N.; Int. J. Environ. Health Res. 2005, 15, 303.

21. Sudakin, A. P. D. L.; Trevathan, W. R.; J. Toxicol., Clin. Toxicol. 2003, 41, 831 .

22. Costanzo, S. D.; Watkinson, A. J.; Murby, E. J.; Kolpin, D. W.; Sandstrom, M. W.; Sci. Total Environ. 2007, 384, 214.

23. http://www.ibama.gov.br/phocadownload/agrotoxicos/boletim de comercializacao_2000_2012.pdf, accessed in January 2018.

24. Annunciação, D. L. R.; Almeida, F. V.; Sodré, F. F.; Microchem. J. 2017, 133, 43.
25. Mavura, W. J.; Wangila, P. T.; Afr. J. Aquat. Sci. 2003, 28, 13.

26. Chiffre, A.; Degiorgi, F.; Buleté, A.; Spinner, L.; Badot, P.-M.; Environ. Sci. Pollut. Res. 2016, 23, 25427.

27. Wilkinson, J. L.; Hooda, P. S.; Swinden, J.; Barker, J.; Barton, S.; Sci. Total Environ. 2017, 593, 487.

28. Kolpin, D. W.; Skopec, M.; Meyer, M. T.; Furlong, E. T.; Zaugg, S. D.; Sci. Total Environ. 2004, 328, 119.

29. Franz, C.; Abbt-Braun, G.; Lorz, C.; Roig, H. L.; Makeschin, F.; Environ. Earth Sci. 2014, 72, 4873.

30. Podsetchine, V.; Schernewski, G.; Water Res. 1999, 33, 3348.

31. https://www.caesb.df.gov.br/balneabilidade-do-lago-paranoa. html, accessed in November 2017.

32. Goldscheider, N.; Haller, L.; Poté, J.; Wildi, W.; Zopfi, J.; Environ. Sci. Technol. 2007, 41, 5252.

33. Ghanem, A.; Bados, P.; Estaun, A. R.; de Alencastro, L. F.; Taibi, S.; Einhorn, J.; Mougin, C.; Chemosphere 2007, 69, 1368.

34. Sonzogni, W. C.; Chesters, G.; Coote, D. R.; Jeffs, D. N.; Konrad, J. C.; Ostry, R. C.; Robinson, J. B.; Environ. Sci. Technol. 1980, 14, 148.

35. Wittmer, I. K.; Scheidegger, R.; Bader, H.-P.; Singer, H.; Stamm, C.; Sci. Total Environ. 2011, 409, 920.

36. Benotti, M. J.; Trenholm, R. A.; Vanderford, B. J.; Holady, J. C.; Stanford, B. D.; Snyder, S. A.; Environ. Sci. Technol. 2009, 43, 597.

37. Abbt-Braun, G.; Worch, E.; Preliminar Report of Project IWASÁGUA DF: Management of Water Resources in Hydrological Sensitive World Regions; Dresden University of Technology: Dresden, 2011.

38. Wang, C.; Shi, H.; Adams, C. D.; Gamagedara, S.; Stayton, I.; Timmons, T.; Ma, Y.; Water Res. 2011, 45, 1818.

39. Focazio, M. J.; Kolpin, D. W.; Barnes, K. K.; Furlong, E. T.; Meyer, M. T.; Zaugg, S. D.; Barber, L. B.; Thurman, M. E.; Sci. Total Environ. 2008, 402, 201.

40. de Jesus Gaffney, V.; Almeida, C. M. M.; Rodrigues, A.; Ferreira, E.; Benoliel, M. J.; Cardoso, V. V.; Water Res. 2015, $72,199$.

41. Chen, M.; Ohman, K.; Metcalfe, C.; Ikonomou, M. G.; Amatya, P. L.; Wilson, J.; Water Qual. Res. J. Can. 2006, 41, 351.

42. Linden, R.; Antunes, M. V.; Heinzelmann, L. S.; Fleck, J. D.; Staggemeier, R.; Fabres, R. B.; Vecchia, A. D.; Nascimento, C. A.; Spilki, F. R.; Braz. J. Biol. 2015, 75, 81.

43. Villanueva, C. M.; Durand, G.; Coutté, M.-B.; Chevrier, C.; Cordier, S.; Occup. Environ. Med. 2005, 62, 400.

44. Rodriguez-Mozaz, S.; de Alda, M. J. L.; Barcelo, D.; J. Chromatogr. A 2004, 1045, 85.

45. Padhye, L. P.; Yao, H.; Kung'u, F. T.; Huang, C.-H.; Water Res. 2014, 51, 266.

46. Qiao, T.; Yu, Z.; Zhang, X.; Au, D. W. T.; J. Environ. Monit. 2011, 13, 3097.

47. Sun, J.; Luo, Q.; Wang, D.; Wang, Z.; Ecotoxicol. Environ. Saf. 2015, 117, 132. 
48. Stackelberg, P. E.; Gibs, J.; Furlong, E. T.; Meyer, M. T.; Zaugg, S. D.; Lippincott, R. L.; Sci. Total Environ. 2007, 377, 255.

49. Snyder, S. A.; Ozone: Sci. Eng. 2008, 30, 65.

50. Jones, O. A. H.; Voulvoulis, N.; Lester, J. N.; Water Res. 2002, $36,5013$.

51. Girling, A. E.; Tattersfield, L.; Mitchell, G. C.; Crossland, N. O.; Pascoe, D.; Blockwell, S. J.; Maund, S. J.; Taylor, E. J.; Wenzel, A.; Janssen, C. R.; Jüttner, I.; Ecotoxicol. Environ. Saf. 2000, 46, 148.

52. Komori, K.; Suzuki, Y.; Minamiyama, M.; Harada, A.; Environ. Monit. Assess. 2013, 185, 4529.

53. Harada, A.; Komori, K.; Nakada, N.; Kitamura, K.; Suzuki, Y.; Water Sci. Technol. 2008, 58, 1541.
54. Ministério da Saúde; Portaria No. 2914, de 12 de dezembro de 2011; Dispõe sobre os Procedimentos de Controle e de Vigilância da Qualidade da Água para Consumo Humano e seu Padrão de Potabilidade; Diário Oficial da União (DOU): Brasília, 2011. Available at http://bvsms.saude.gov.br/bvs/ saudelegis/gm/2011/prt2914_12_12_2011.html, accessed in January 2017.

55. Meltzer, H. M.; Alexander, J.; Elind, E.; Lam, H. R.; Liukkonen, K.; Petersen, M. A.; Solbergsdottir, E. J.; Risk Assessment of Caffeine Among Children and Adolescents in the Nordic Countries; Nordic Council of Ministers: Copenhagen, Denmark, 2008.

56. Montagner, C. C.; Umbuzeiro, G. A.; Pasquini, C.; Jardim, W. F.; Environ. Sci.: Processes Impacts 2014, 16, 10.

Submitted: November 13, 2017 Published online: March 22, 2018 